\title{
SMIF Model With Maqashid Sharia-Based
}

\author{
Anas Alhifni', Biyati Ahwarumi² \\ Universitas Djuanda Bogor ${ }^{1,2}$ \\ Jalan Tol Ciawi No 1 Kotak Pos 35 Ciawi, Bogor, Jawa Barat ${ }^{1,2}$ \\ E-mail : anas.alhifni@unida.ac.id ${ }^{1}$, ahwarumi@gmail.com²
}

Diterima: 6 Juni 2018; Direvisi: 27 Juni 2018; Diterbitkan: 5 Juli 2018

\begin{abstract}
Abstrak,
Lembaga keuangan mikro syariah adalah lembaga keuangan yang lebih berorientasi pada masyarakat menengah ke bawah. Keberadaannya untuk semua agama dan perannya harus lebih dioptimalkan untuk memberikan kesejahteraan bagi anggota dan masyarakat secara umum. Tulisan ini bertujuan untuk menjelaskan filosofi dasar lembaga keuangan mikro syariah dan bagaimana konsep lembaga keuangan mikro syariah sesuai dengan nilai maqashid syariah. Metode yang digunakan adalah metode kualitatif dengan teknik analisis data analisis konten. Hasil penelitian ini menunjukkan bahwa perbedaan mendasar antara lembaga keuangan mikro syariah dan lembaga keuangan konvensional ditemukan dalam filsafat nilai-nilai moral sesuai dengan teks-teks Al-Quran dan hadits. Sebagai lembaga keuangan SMIF maqashidsyariah berbasis yang dapat menjamin setiap produk yang mampu memberikan manfaat bagi orang untuk mencapai Fallah atau kesejahteraan, seperti memprioritaskan produk bagi hasil, dan menjaga tujuan sebagai bisnis dan lembaga keuangan sosial.
\end{abstract}

Kata Kunci: SMIF, Maqashid Syariah

\begin{abstract}
, Islamic microfinance institution is financial institution that is more oriented to the middle and lower community. Its existence is for all religions and its role should be further optimized to provide welfare to members and community in general. This paper aims to explain the basic philosophy of Islamic microfinance institution and how the concept of Islamic microfinance institution in accordance with maqashid sharia values. The method used is qualitative method withanalysis techniques of data content analysis.Result of this article shows that the fundamental difference between Islamic microfinance institution and conventional finance institutionfound in the philosophy of moral values in accordance with texts of the Al-Quran and hadith. As maqashidsyariah-based SMIF financial institution that can guarantee every product that is able to provide benefits for people to reach Fallah or welfare, such as prioritizing profit sharing products, and keep the goal as business and social financial institution.
\end{abstract}

Keywords: SMIF, Maqashid Sharia

\section{INTRODUCTION}

Islam is the religion that governs all sides of human life, then no single aspect of human life irrespective withIslamic teaching, including economic or muamalah, in Islam muamalah 
already become rules of the game or the rules of man in running their life (Antonio 2010). In the modern era economic activities would not be complete without the presence of financial institution, in general, economic and financial issues are included in muamalah chapter, the Prophet Muhammad SAW did not give detailed rules on the matter, as his statementyou are better know with your-own affairs, so the scholars make the rules ushuliahbasis in muamalah is allowed unless there is the argument texts that forbid it (Ramadhan 2007). GenerallymuamalahMaliyah is synonymous with money as a medium of exchange or a legal payment, in the Ushuliahrules there is a rule that states that something that should be there to enhance mandatory, it shall be held (Az-Zuhaili, 1982), therefore the existence of financial institution is obligatory because it can enhance mandatory because it may cause welfare and facilitates financial transactions communities to meet their needs. In general, Al-Qur'an and Sunnah already provides basic principles and philosophy as well as stressing the prohibitions should be avoided, thus have to do is to identify things that are forbidden by Islam, in muamalah everything is allowed and we can innovate and creativity as much as possible, therefore, the relationship between Islam and financial institution became clear (Karim, 2004).

According to Chapra (2001) and Alhifni et al (2017) despite the close relationship between Islam and financial institution, but Islam faced with problems of the growth of Islamic financial institution, especially in Islamic finance where its products are still to consumer goods-oriented, so it requires fresh idea under the guidance of the texts and maqashid ash-sharia and modern reality to get an effective solution so that the presence of microfinance institution clearly can have a positive impact on community. Islamic microfinance institution ismicrofinance institution at grass roots in the middle and lower community, but until now the existence of Islamic microfinance institution in Indonesia has not been functioning as its main purpose is to provide benefit to the community or ummah. Thus the need for development model of Islamic microfinance institution based on maqashid sharia. The existence of Islamic microfinance institution is expected to have positive impact, especially in improving public welfare were reviewed based on maqashidsyariah values.Maqashidsharia is the purposes of sharia that should be run simultaneously and substantially realized to achieve falah (happiness of the world and Hereafter).

There are several research questions in this paper. First, what is the basic philosophy of Islamic microfinance institution? Second, how the difference between philosophies conventional microfinance institutionandIslamic microfinance institution? Third, how the model of Islamic microfinance institution based on maqashid sharia? 


\section{LITERATURE REVIEW}

Maqashid مقاصد is a plural form of word قصد meaning of the goal or target. As for terminology as disclosed Ar-Risuni (1994) definition ofmaqashid sharia is:

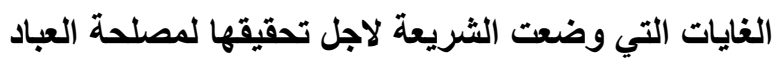

Meaning: "The goal to be achieved by the law to achieve the benefit of Ummah.

As according to Sahroni and Karim (2015) definition of maqashid sharia is:

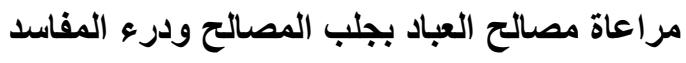

Meaning: "Fulfilling human needs by realizing the maslahah and avoid mafsadah of them.

According to Sahroni and Karim (2015) every maslahat contained in maqashid is every maslahah in the form of a favor or benefit to be achieved and the harm to be avoided, so in the essence maqashid is the goal to achieve benefit, maqashid sharia also serves to strengthen the legal content and the wisdom behind the law. Based on the above definitionsauthor try to define that maqashid sharia are objectives of the Shari'a to provide benefit and happiness of humankind to achieve Fallah, and if it is connected with the context of microfinance institution of Islam, then every microfinance institution Islam must have maqashid sharia values or benefit for community which is reflected in its operational activities and its products.

Ar-risuni (1994) divides maqashid sharia in five forms of maqashidas folows:

1. Hifdzu din

2. Hifdzunafs

3. Hifdzuaql

4. Hifdzu mal

5. HifdzuNasab

There are five kinds of maqashid sharia stratified according to their needs and interests' rate, the needslevel is divided into three:

1. Dharuriyat

Dharuriyat are basic needs that must be met, and if not fulfilled, can cause harm, such as obligation of fasting inRamadhan, daruriyat needs can also be referred to as primary needs such as cloth,food and house.

\section{Hajjiyat}

Needs that should be met and if not fulfilled, then will cause trouble, like someone is allowed for not fasting in Ramadan due to sick, if fasting it will cause hardship to him. Hajjiyat needs can also be referred to as secondary needs.

\section{Tahsiniyyat}

Complementary needs and if not met will not be a disadvantage, such as people who are not fasting in Shawwal fasting. Tahsiniyat needs can also be referred to as tertiary needs. 
Islamic microfinance institution (SMIF), BMT or KJKS, KSPPS, UJKS is integrated independent business center who developing productive efforts and investments to improve the quality of economic activity, or can be called as an institution that provides deposit, financing and payment services of various transaction services aimed for middle and lower community and small entrepreneurs on the basis of mutual assistant and managed based on sharia principles (Muhammad, 2009, Salidin, 2000). In general SMIF was formed as a cooperative, this actually happened by accident because microfinance institution under Ministry of Cooperatives and SMEs, therefore the ministry directs BMT or SMIF be obtained facility from government (Rahardjo,2008)

The characteristics of SMIF or BMT by Salidin (2000) are as follows:

1. Business-oriented, looking for-profit joint, improve economic utilization of most for members and its environment.

2. Not a social institution, but can be used to make effective the use of ZISWAF (zakah, infaq, charity and endowments).

3. Grow from bottom based on participation of the surrounding communities.

4. Joint owner and joint controlledby small community of the BMT environment itself, and not to a specific person.

5. Prioritizing the movement of saving rather than loan.

The function to be performed by SMIF or BMT by Huda and Heykal (2013) are as follows:

1. Fund collection and distribution by saving money in SMIF or BMT, the money can be enhanced utility, which raised the surplus unit.

2. Creator and liquidityprovider, could create legal payment that can provide ability to meet obligations of an institution or individual.

3. SMIF or BMT income sourcescan create new jobs and provide income to their employees proportionally.

4. An information provider, provide clear information to the public regarding the risks, benefits, and opportunities that exist in the financial institution.

5. As SMIF or BMT can provide financing for community and SMEs by not to burden the enforcement of collateral.

\section{METHODS}

The method used is descriptive qualitative method, as for data collection techniques usingdocument data of some literature such as journal, book and more, and then analyzed using content analysis technique. 


\section{DISCUSSION}

\section{Philosophy of Islamic Micro Finance Institution}

Islamic microfinance institutionhave a very clear philosophical basis as other Islamic economic institution, Islamic microfinance institutionhave the same reference to the Islamic economic system and an integral part (Buchori, 2012). As stated in the QS. Al-Baqarah verse 208 as follows:

Meaning: "O you who have believed, enter into Islam completely [and perfectly] and do not follow the footsteps of Satan. Indeed, he is to you a clear enemy. "(Q.S Al-Baqarah: 208)

Based on the above verse it can be explained that Islam is a perfect religion and covers all aspects of life, Islam does not only regulate the worship affairs, but Islam also regulate all aspects of life including economic and so on. So we are as Muslims can be as true Islam and can apply it in every aspect of life, including financial aspects. The existing system in SMIF is part of the universal Islam values and teachings, as an example of economic activity generally consists of the production distribution and consumption, short term and long term savings, and investment through a pattern of buying and selling and profit-sharing, from all humans are required to ensure the halal status of started to get it up to the distribution should be in accordance with Islamic law. Humans need something to fulfill their unlimited needs, but people should not forget the essence of man creation is to worship to God Almighty. Islam calls for a balance between worship and muamalah or in looking for supplies the world and hereafter, as Allah decree in QS. Al Qasas verse 77:

meaning: "But seek, through that which Allah has given you, the home of the Hereafter; and [yet], do not forget your share of the world. And do good as Allah has done good to you. And desire not corruption in the land. Indeed, Allah does not like corrupters. "(QS. Al-Qasas: 77 )

In order to realize all of the existence of Islamic microfinance institutionas one of the institution that must provide halal and good financial services for its members and in general for the people, as the following verse:

That is; "O mankind, eat from whatever is on earth [that is] lawful and good and do not follow the footsteps of Satan. Indeed, he is to you a clear enemy.. "(Q.S al-Baqarah: 168).

Islamic microfinance institution is not only required to provide halal and good services, but the most important the existence of Islamic microfinance institution isthat the institution run within the framework of mutual help among member of Islamic microfinance institution where members of Islamic microfinance institution who have surplus funds can help member Islamic microfinance institutionthat does not have sufficient funds, as in the following verse:

meaning: ... "And cooperate in righteousness and piety, but do not cooperate in sin and aggression. And fear Allah ; indeed, Allah is severe in penalty.. "(QS. Al-Maidah: 2) 
Based on the above verses it can be explained that Islamic microfinance institutionhave a strong philosophical foundation so that the existence of these institution is not just distributing funds on consumer, but the most important thing is how the Islamic microfinance institutioncan distribute their funds on productive things and do coaching so as to motivate the soul enterpreuner community the importance of working with the concept of halalan thayyiban reached falah or happiness in the world and hereafter.

\section{Philosophical Differences of Conventional and Islamic Microfinance Institution}

Business philosophy covers a large area and covers various aspects such as beliefs, practices, and guidelines to be followed by financial institution in carrying out its business operations. Business philosophy in Islam teaches patterns and forms of cooperation organized by the Islamic microfinance institution to its members. Khan (1995), states that the purpose of Islamic financial institution is to develop, maintain and improve the use of the principles of Islamic laws and traditions in all transactions, finance, business and other business activities.

In general, microfinance institution is the same function with Sharia microfinance institution, namely as funds distribution institution from surplus units to deficit units customers. However, the surplus units on Islamic microfinance institution acting as investors or funds deposit treated by sharia. The fund is managed in a halal manner anddistributed by Islamic microfinance institution in financing customers for a variety of purposes, of the financing, microfinance institution will obtain profit-sharing or marginas revenue ofIslamic microfinance institution. Thus, financing customers will pay the principal and profit sharing to Islamic banks. This means that the funds from the customer should be sought in advance to generate revenue then paid for the result (applies inmudharabah agreement), the revenue will be divided for Islamic banks and customers benefit the funds in accordance with the agreed ratio. Philosophy of conventional and Islamic microfinance institutionis very different, as illustrated in the following table: 
Tabel 1

Philosophy of Conventional and Sharia Financial institution

\begin{tabular}{|c|c|c|c|c|}
\hline NO & $\begin{array}{l}\text { MICROFINANCE } \\
\text { INSTITUTION }\end{array}$ & ONTOLOGY & EPISTEMOLOGY & AXIOLOGY \\
\hline 1 & Conventional & $\begin{array}{l}\text { Idealism } \\
\text { Materialism }\end{array}$ & $\begin{array}{l}\text { Funding, Financing, } \\
\text { Service Based non halal } \\
\text { and halal }\end{array}$ & $\begin{array}{ll}\text { - } & \text { Interest, haram } \\
\text { • } & \text { اتنا فى الدنيا حسنه }\end{array}$ \\
\hline 2 & Sharia & $\begin{array}{l}\text { - Islamic Values } \\
\text { (tauhid ) } \\
\text { - Siddiq, Amanah, } \\
\text { Tabligh, Fathonah. } \\
\text { - Fair } \\
\text { - Unity } \\
\text { - Helping } \\
\text { - } \text { Partnership }\end{array}$ & $\begin{array}{l}\text { Funding, Financing, } \\
\text { Service Based halal } \\
\text { and Thayyib }\end{array}$ & $\begin{array}{l}\text { - Profit sharing, } \\
\text { patnership } \\
\text { - التا فى الدنيا حسنه وفى حسنه } \\
\text { الاخرة }\end{array}$ \\
\hline
\end{tabular}

Source: compiled from a variety of sources

Tabel 2

Differences in Conventional and Sharia MFI

\begin{tabular}{|c|c|c|}
\hline $\begin{array}{c}\text { TYPES OF } \\
\text { DIFFERENCE }\end{array}$ & SHARIA MFI & CONVENTIONAL MFI \\
\hline Philosophy & $\begin{array}{l}\text { Al Qur`an, Sunnahand Positive } \\
\text { Law }\end{array}$ & Positive Law \\
\hline Basis Operational & Profit sharing & Interest \\
\hline Product Scheme & $\begin{array}{l}\text { Based on the principles of sharia- } \\
\text { contract such as mudaraba, } \\
\text { wadiah, murabaha, Musharaka } \\
\text { etc. }\end{array}$ & Based on positive law contract \\
\hline $\begin{array}{l}\text { Treatment to the } \\
\text { public funds }\end{array}$ & $\begin{array}{l}\text { Public funding is a surrogate / } \\
\text { new investments get results when } \\
\text { administered on productive } \\
\text { business halal }\end{array}$ & $\begin{array}{l}\text { Public funding is a deposit to be paid } \\
\text { interest at maturity }\end{array}$ \\
\hline Fund distribution & Must be halal, tayyiban & $\begin{array}{l}\text { Not considering halal / haram (must } \\
\text { be profitable ) }\end{array}$ \\
\hline Organization & There is Sharia Supervisory Board & N/A \\
\hline
\end{tabular}

Source: compiled from a variety of sources

\section{Islamic Microfinance Institution Development Model Based on Maqashid}

\section{Sharia Values}

In general, these products are already illustrates that Islamic microfinance institutionalready havemaqashid sharia values, the first الدينحفظmicrofinance institution can be used by all religions, not only Islam, SecondالعقلحفظIslamic microfinance institution already 
hasvarious saving deposits model such as education savings, and there are scholarships from the funds ZISWAF, third المالحفظIslamic microfinance institution already has service funding, financing, service-based (ZISWAF) which is run in accordance with islamic principles, fourth Islamic microfinance institution already has services such as financing for working capital, profit and loss sharing, fifth النسلحفظIslamic microfinance institution already has products for the long term for students and so on. But of all the things that need to be reviewed further, the first is the existence of Islamic microfinance institution already providebenefit? Second if Islamic microfinance institution have been operated in accordance with its function? The questions need to be explored further so as to provide a comprehensive answer as the following discussion.

1. Review of maqashidsharia linked to microfinance institution

a. حفظ الدينaccording to Al-Ghazali and As-Syathibidefinition of keeping religion is penalty for leaving the religion of truth, but in its development experts ofmaqashid sharia try explain with a broader definition, such as freedom of religion (Auda, 2008), according to the author if connected with the financial institution where Islamic microfinance institution not only for Moslem but its entry to the whole of mankind is a characteristic of al-'alamin mercy. Keepingmember's religion. This is manifested throughout the operational and its products are run according to the principles of the Qur'an, hadith, consensus and Qiyas, Islamic microfinance institution should have sharia supervisory board as well as the Islamic Bank, it is intended that the values and rules of Islam more secure so that it can believed by Moslem and non-Moslem.

b. حفظ العقلaaccording to Al-Ghazali and As-Syathibi definition ofkeeping a sense is the prohibition to drink alcohol or intoxicating, but in its development experts maqashid sharia try to define the scientific development, studying, against the taqlid mentality, traveling to study and so on related to education (Auda, 2008), according to the author if linked financial institution where Islamic microfinance institution should be able to provide services or facilities to develop education in the form of funding, financing and service based. Keeping minds of customer fromusury in the Al-Quran who devour usury like intoxicated and healthy when all his wits to be more profitable. It is realized from the demands that the Islamic microfinance institution must always reveal more details about the product and the system did not cover up the slightest. Here we see that customers are asked to think tog ether when doing transactions at the institution without being tyrannized by microfinance institution,microfinance institution can also educate its members well. 
c. حفظ المالaccording to Al-Ghazali and As-Syathibi definition of keeping the treasure is the punishment of hand amputation for thieves and protection money, but in its development experts maqashid sharia try to define social assistance, economic development, distribution of money, prosperous communities and gap reduction (Auda, 2008), according to the author in relation to the financial institution where Islamic microfinance institution should be able to provide services either in the form of funding, financing or service-oriented based on something productive to improve the welfare of the community, such as the financing is, muzara'ah, musaqah, mukhabarah, deposits mudaraba, Islamic microfinance institution also required to provide guidance in the form of assistance and supervision. Keeping the assets. This is clearly realized in each of the products issued by Islamic microfinance institution where Islamic microfinance institution have to maintain and allocate customers with good and lawful and allowed to take profit reasonable, assets managed if it has reached nishab obliged to pay zakat, because zakat is cleaning of treasure.

d. حفظ النفسaccording to Al-Ghazali and As-Syathibi definition of keeping the soul is sentenced to qisasformurder, but in its development maqashid sharia experts aretry to define human rights, protection of their rights and dignity (Auda, 2008), according to the author if connected with the financial institution where the financial institution should be able to give the rights of its members in a fair manner, and get easy access. Keepingcustomer's soul. It is realized from agreement applied in any transaction in Islamic microfinance institution both psychologically and sociologically usage-contract agreement executed with mutual respect and maintain trust. This is where the value of his soul will be maintained. In addition, it is also realized from stakeholder of Islamic microfinance institution which in the face of the customers are required to behave, dress and communicate politely and Islamic.

2. according to Al-Ghazali and As-Syathibi definition of keeping the soul is the punishment for violators of decency or keep the pubic, or at necessity level, in the development the experts of maqashid sharia try to define oriented moral values for the family (Auda, 2008), according to the author in relation to financial institution where financial institution should be able to give moral values for each members, or provide training to its members to increase awareness of saving and investment so as not to leave weak children and grandchildren, if the property is given is halal it will have a positive impact on the offspring and the offspring will be maintained. This is realizedin 
four items above, the member'sfund that has operated with halal principles will have a positive impact on families and offspring thatfinancewith the invested funds. Maqashid Study linked to Islamic Micro Finance Institution Products

In Islamic law there are two things that must be distinguished, namely al-Maqasid (goal) and al-Wasail (medium). The purpose is reached for the benefit and refused mafsadat. How to convey the benefit is calledfath al-dzariah (opening road). As for how to avoid mafsadatis called sadd al-zariah (closing the road) (Zahra, 1994). Islamic Economics is a new paradigm to solve economicalproblems in Islamic ways. In ushulfiqhthere is a principleswhich states:

$$
\text { مالايتم الوجب الابه فهو واجب }
$$

Meaning: "something that should be there to enhance mandatory, it shall be held."

Earn living (in conducting economic activity) is mandatory. And because in this modern era economic activities would not be perfect without any financial institution, the financial institution is also required to be held. From the rules above can be explained that the current system used in the business of financial institution so that the majority financial institution use the usury concept sofinancial institutionwho do not use usury shall be held, in other fiqh rules mentioned:

$$
\text { ما ادى الحرام فهو حرام }
$$

Meaning: "Anything that led to haram then it is also haram".

Two principles above originalyfromushulfiqhprinciple because it is a principle inistibath (fath al-dzariah and sadd al-dzariah) and recognized by all madzhab (Zahra, 1994). Raising funds productin Islamic microfinance institution between depositbased contractand profit sharing are permissible in Islam, as well as funds distribution product that sales \& purchase-oriented contract withTaqshith or muajjal-based and naqdan with profit sharing contract sharing all allowed by Islam, as in the fiqh rules basically in every muamalah and transactions are allowed, such as, consignment, sale and purchase, lease, mortgage, cooperation murabaha, musharakamuzara'ah, mukhabarabh and musaqah and much more unless there are texts that forbid or the cause of disadvantage, deception, gambling and usury, then can not be allowed.

Generally, there are three priorities in the maqasid sharia, are:

a) Daruriyator mandatory or necessity is something that must be there for the survival of human life. Interest of daruriat itself is saving religion, soul, mind, wealth, lineage and self-esteem (hurmah, pride, or honor) ( Auda, 2008 ). 
b) Hajjiyator necessity meaning something that required for survival of human life. If no available it will not be destroying, but encountered difficulties (Auda, 2008).

c) Tahsiniyator decorative-ornamental processes meaning the absence of decorative-ornamental will not be destroyingbut the presence will facilitate the achievement of the goals (Auda, 2008).

In general, Islamic microfinance institution is responsible and ensure that the savings people are managed in accordance with halal principles when micro financeinstitutiondistribute funds in the form of buying and selling taqshith then arising is the debt that must be paid under contract that has been agreed upon, if viewed from benefit context the advantages of sales and purchase-based financing (murabaha, salam, istishna). The margin obtained by microfinance institution very large with antaradinminkum terms and can be used to develop Islamic microfinance institution.

inprinciples:

$$
\text { مر اعة المقا صد مقدمة على رعاية الوسائل ابدا }
$$

Meaning: "keep (preserve) the purpose always take precedence over maintaining means (media) to achieve goals"

Based on theprinciple, the purpose of maintaining Islamic microfinance institution namely the creation of maqasidsyariah (keeping religion, soul, mind, wealth, lineage and selfesteem), and more precedence than maintaining the way in achieving that goal. Method or media-contract is a contract used by Islamic micro financial institutionboth sale and purchasebased (murabaha, salam, istishna, Ijara) and profit sharing-based.

But of all of modelsprofit sharing system that is supposed to be the main product in Islamic microfinance institution. Products of good Islamic microfinance institutioneither financing or service based in the hajiatcategory (needs) because of the economic activities of Moslems are require agencies that regulate and facilitate economic activities.

According to Auda (2008) between dharuriat, hajjiyat and tahsiniyat must be harmonious and becomes important to run everything, so the use of funding products, financing, profit sharing based (long term Wadiah, mudaraba deposits, Mudaraba financing, Musharaka, muzara'ah, Musaqah and Mukhabarah) and service-based (QardulHasan, Zakat distribution) in maqasidsyariah contemporary should be the main products for Islamic microfinance institution, this is done to keep dharuri for the sake of the ongoing Islamic microfinance institution for the future, and provide assistance significantly and simplify people in meeting their economic needs. The hajjiyat is such (murabahafinancing, salam, istishna, Ijarah and Rahn), the latter is tahsiniyat (Wakalah, kafalah, HiwalahQard) and developing products that attract the technology base so that people believe in full by the 
presence of Islamic microfinance institution. When the Islamic microfinance institution can be run in accordance with the function bring positive impact, especially in creating Human Welfare and Welfare state. Clearly can be described as follows.

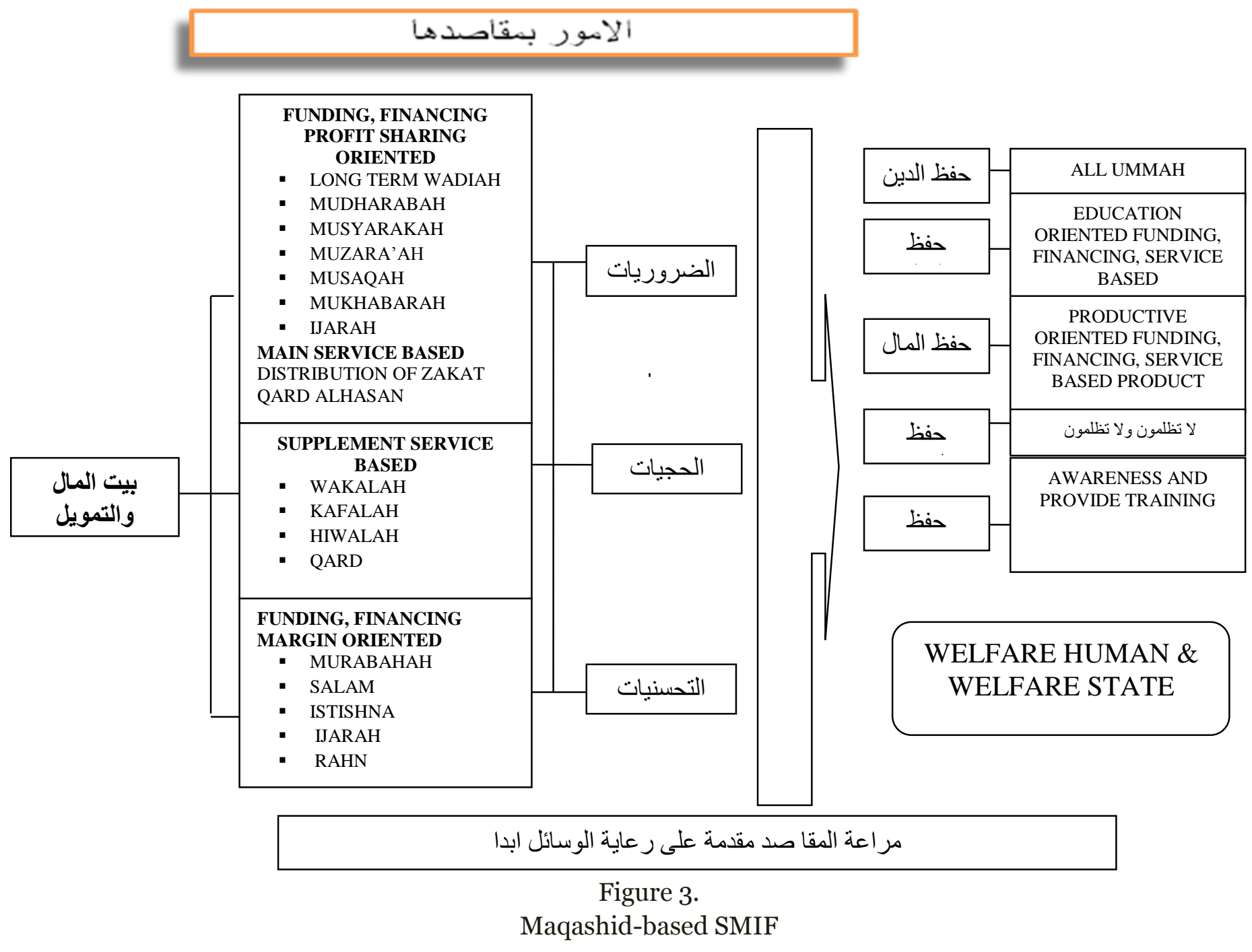

\section{CONCLUSION}

First,SMIFhas a philosophical basis in accordance with the Al-Quran and hadith. Second, fundamental difference between Islamic microfinance institution and conventional lies on the philosophy of moral values in accordance with the texts of the Al-Quran and hadith.The concept of financial institution based on maqashid is any existing products must provide maslahat impact for the people to reach fallah or welfare, such as prioritizing products for the results, and maintaining its purpose as business and social financial institution. 


\section{REFERENCE}

Alhifni et al. 2017. Waqaf An Instrument of Community Empowerment In Islamic Boarding School Daarut Tauhiid In Indonesia. JIEBF, Vol. 13 No. 2 Ed. April - June, Page 7688.

Antonio, Muhammad Syafi'i. 2010. Bank Syariah Teori dan Praktik. Jakarta: Tazkia Cendekia.

Auda, Jasser. 2008. Membumikan Hukum Islam Melalui Maqshid Syariah. Jakarta: Mizan

Az-Zuhaili, Wahbah. 1982. Al-Fiqh al-Islamiwa Adillatuh Jilid VI. Damaskus: Darul Fikri.

Ar-Risuni, Ahmad. 1994. Nadzariyatul Maqashid'inda Al-Iman As-Syathibi. Kairo: International Istitute Of Islamic Thought (IIT ). Printed IV.

Buchori. Nur S. 2012. Koperasi Syariah. Jakarta: Aufa Media.

Chapra, M. Umer. 2001. The Future of Economics An Islamic Perspective. Landscape Baru Perekonomian Masa Depan diterjemahkan oleh Amdiar Amir. Jakarta: Shari'ah Economics and Banking Institute.

Huda, Nurul. Heykal, Muhammad, 2013. Lembaga Keuangan Islam, Tinjauan Teoritis dan Praktis. Jakarta: Kencana.

Karim, Adiwarman A. 2004. Bank Islam. Analisis Fiqih dan Keuangan. Jakarta: PT. Raja Grafindo Persada.

Khan, Fahim. 1995. Essay In Islamic Economy. The Islamic Foundation

Muhammad. 2009. Lembaga Keuangan Mikro Syariah. Yogyakarta: Graha Ilmu.

Rahardjo, Pratama dan Mandala Manurung. 2008. Pengantar Ilmu Ekonomi (Mikroekonomi \& Makroekonomi) Edisi Ketiga. Jakarta: FE UI.

Ramadhan, Athiyah. 2007. Al-Mausu'ah al-Qawa'id al-Fiqhiyyah Lil Mu'amalat al-Maliyah. Darul Iman Al-Iskandariyah.

Sahroni, Oni dan Adiwarman Karim, 2015. Maqashid Bisnis dan Keuangan Islam Sintetis Fikih dan Ekonomi. Jakarta: Raja Grafindo.

Salidin, Djaslim. 2000. Konsep Dasar Ekonomi dan Lembaga Keuangan Islam. Bandung: Linda Karya.

Zahra, Abu, Muhammad. 1994. Ushul Fiqih. Damaskus: DarulFikri 